\title{
Comparative Ontogeny of Hermaphrodite and Pistillate Florets in Helianthus annuus L. (Asteraceae)
}

\author{
Aslıhan ÇETINBAŞ ${ }^{*}$ Meral ÜNAL \\ Marmara University, Department of Biology, Göztepe Campus, 34730 Istanbul, Turkey; aslihancetinbas1@hotmail.com (*corresponding author)
}

\begin{abstract}
The inflorescence of Helianthus annuus L. has two types of flowers (or florets) on a single capitulum; central hermaphrodite disc florets and peripheral pistillate ray florets. In both florets, reproductive development starts with the conversion of apical meristem into floral meristem that will produce floral organ primordia. The only difference between hermaphrodite and pistillate florets in apical meristem stage is that apical meristem of the pistillate florets is not as apparent and curvaceous as apical meristem of the hermaphrodite florets. The differentiation of apical meristem into floral meristem is in the same progress in both florets. In hermaphrodite florets, flower organs; petals, stamens and carpels develop from floral meristem. Differentiation of five petal primordia takes place in the same way in both florets. Firstly filament and then anther differentiates in a stamen. Two carpel primordia appear below the stamen primordia in hermaphrodite florets. In following stages, carpel primordia are lengthened and formed inferior ovary, style, stigma respectively. In pistillate florets, flower organs; petals and carpels develop from floral meristem. They pass directly from the periant initiation to the start of carpel formation. Stamen primordia don't appear and the further development of carpel primordia stops in a short time, as a result, stigma and style do not exist in pistillate florets. However, an inferior ovary with no ovule forms. In the capitulum of hermaphrodite florets, the development takes place in a centripetal manner; it starts firstly on the outermost whorl, and it proceeds towards inner whorl. However, this is not the case in pistillate florets.
\end{abstract}

Keywords: apical meristem, floral meristem, flower ontogeny, Helianthus annuus L., hermaphrodite florets, pistillate florets

\section{Introduction}

Helianthus annuus is a member of Asteraceae (Compositae), which is the largest family of flowering plants, with approximately 1620 genera and more than 23.600 species (Anderberg et al., 2007). The family Asteraceae is characterised by a capitulum which is a specialised indeterminate inflorescence containing one to hundreds of flowers (or florets) (Harris, 1999). The inflorescence of $H$. annuus has two types of florets on a single capitulum; hermaphrodite and pistillate. The outer whorl is defined by pistillate ray florets (Heiser, 1976; Hurd et al., 1980). The remainder of the capitulum is filled with hermaphrodite, disc florets (Frankel et al., 1977; McGregor, 1976; Knowles, 1978).

The start of flower bud development comprises the differentiation of vegetative meristem, its conversion into apical meristem and its transformation over again, into floral meristem in the upcoming stage (Bernier et al., 1993). Flower organs; sepal, petal, stamen and carpel develop from floral meristem (Atsmon and Galun, 1960; Malepszy and Szczytt, 1991), but further development of stamen or pistil is selective, resulting in unisexual flowers (Haughn and Somerville, 1988; Rastogi and Sawhney, 1988).

Hermaphrodite flowers are bisexual with both stamen and pistil. Pistillate flowers are unisexual with pistil only (Dellaporta and Calderon-Urrea, 1993). Stamen primor- dia either never develop or degenerate after a time from initiation. For instance, in the pistillate flowers of Laurus nobilis, filaments emerge, however, anther development is arrested, and stamens become non-functional staminods (Aytürk and Ünal, 2012). In dioecious Silene latifolia, both stamen and carpel primordia are present in both sex, with the developmental arrest of the inappropriate sex occuring at early stages of floral development (Ye et al., 1991). The arrested development of sex organs is not accidental; it is manipulated by the environmental conditions and genotype (Kinet et al., 1985). The spectrum of unisexual flower development revolutionizes from the differentiation of organ primordia until the formation of sex organs, which are completely developed but non-functional (Dellaporta and Calderon-Urrea, 1993). Asteraceae is a favorite family for ontogenic studies because of different types of flower in the centre and periphery of a capitulum, various types of calyx and corolla, syngenesious androecium and inferior ovary with a single ovule.

Despite extensive embryological and morphological studies in Helianthus annuus L., little is known about flower ontogeny. The purpose of this study is to find out the comprehensive description of hermaphrodite and pistillate florets ontogeny. Also, this study is aimed to understanding the sexual differentiation and the arresting stage of male and female organs in pistillate florets of sunflower. 


\section{Materials and methods}

The capitulum of $H$. annuus at various stages of development were collected from Tekirdağ (Turkey). Firstly, the diameter of capitulum were measured, hermaphrodite and pistillate florets were morphologically analysed by stereomicroscope (Olympus 970931). The samples were prepared for light and SEM analysis. The material was fixed in acetic-alcohol $(1: 3, \mathrm{v} / \mathrm{v})$ and then placed in a vacuum desiccator to facilitate the penetration of the fixative into the plant tissues. After embedding in paraffin, blocks were sectioned at $8-15 \mu \mathrm{m}$ by Leica RM2235 rotation microtome and sections were stained with hematoxylin. The preparations were photographed with an Evolution LC color camera and an Olympus BH-2 microscope, and the images were analyzed with Image-Pro Express Version 6.0 scientific image processing and analysis software. For SEM analysis, the plant material was fixed in $2.5 \%$ glutaraldehyde in $50 \mathrm{mM}$ cacodylate buffer, pH 7.0 (Platt et al., 1983) and then dehydrated with an increasing ethanol gradient: from $70 \%$ up to $100 \%$. Then, the material for drying were kept in various percentages of ethanol-HMDS solution at room temperature (Topçuoğlu et al., 2009). Then, coated with $11 \mathrm{~nm}$ of gold by using an automated sputter coater and then examined with a SEM (JEOL JMS-59 10LV).

\section{Results}

\section{Flower (or floret) morphology}

The inflorescence of $H$. annuus has two types of flowers (or florets) on a single capitulum; central, hermaphrodite disc florets and peripheral pistillate ray florets.

Hermaphrodite florets lack a leafy calyx and have tubular or disc corolla that is composed of five equivalent petal lobes (Fig. 1B) and pappus. The base of corolla is surrounded by a specialized structure, pappus which is shorter than petals (Fig. 1A). Hermaphrodite florets have five stamens, with free filaments and fused anthers that produce a tube surrounding the style (Fig. 1C, D; Fig. 3C). The tops of the anthers have trichomes (Fig. 3B, D). Style shows

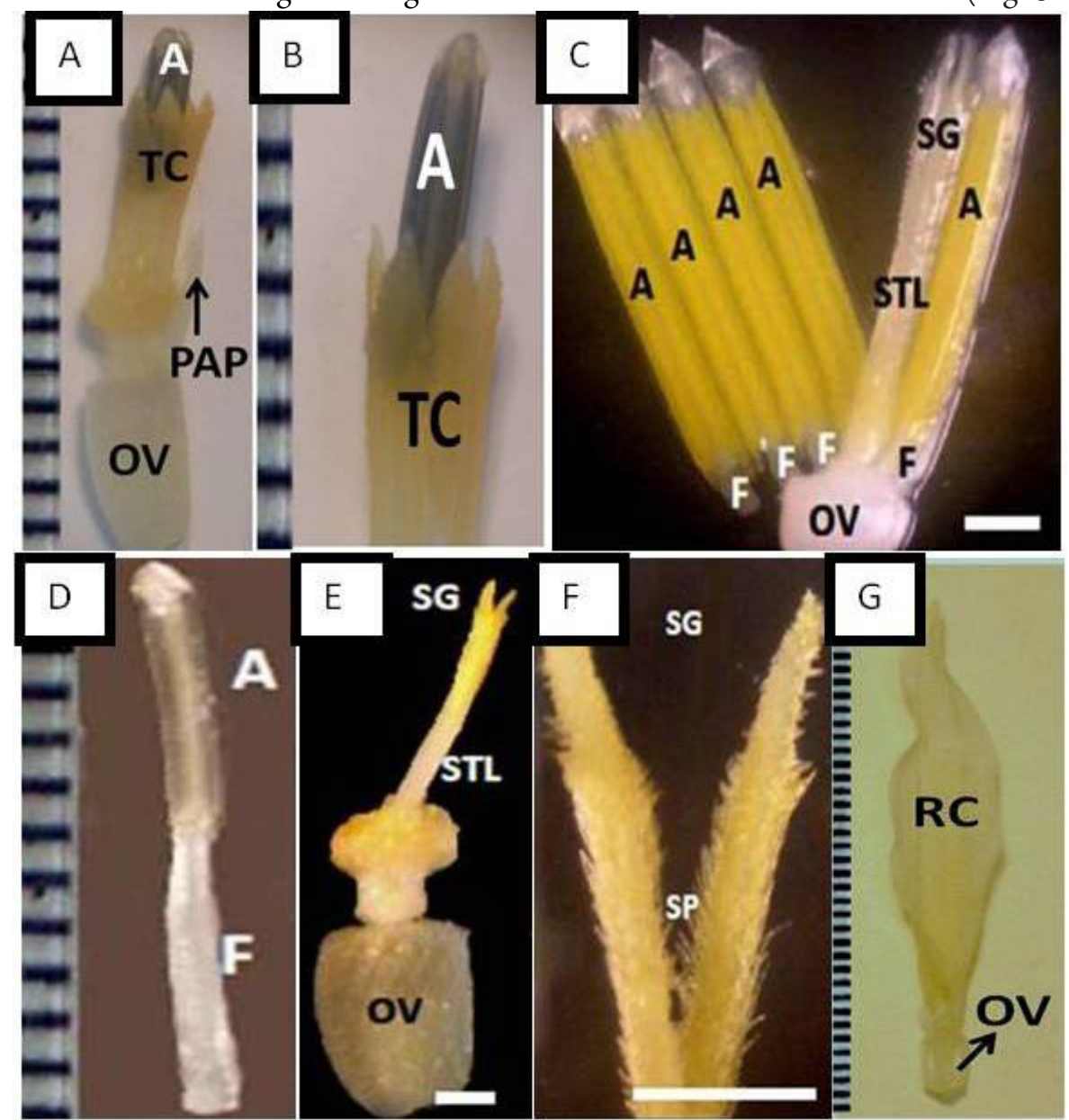

Fig. 1. Hermaphrodite (A-F) and pistillate (G) florets viewed by stereomicroscope in $H$. annuus. A. Pappus; B. Tubular corolla; C. Anther tube which removed under the stereomicroscope and stamens with free filaments and fused anthers; D. Anther and filament; E. Stigma, style and inferior ovary; F. Stigmatic branches and stigmatic papillae; G. Ray corolla and inferior ovary with no ovule. A: Anther; F: Filament; PAP: Pappus; OV: Ovary; RC: Ray corolla; SG: Stigma; SP: Stigmatic papillae; STL: Style; TC: Tubular corolla. Bar: $1 \mathrm{~mm}$ 
32

a straight appearance. Stigma is two-lobed and receptive surface is papillose (Fig. 1F; Fig. 4B). Unilocular and inferior ovary contains one ovule (Fig. 1E). Hermaphrodite florets are fertile.

Pistillate florets have ray corolla that is composed of five unequivalent petal lobes. These florets have not stamens but, have inferior ovary with no ovule (Fig. 1G). Stigma and style are not developed. Pistillate florets are sterile.

\section{Initiation of floral meristem}

Development in hermaphrodite and pistillate florets start with the differentiation of apical meristem (Fig. 2A, B). Apical meristem appears as a roundish bulge and consists of sequential cell layers. Afterwards, apical meristem starts to become flattened and transforms into floral meristem (Fig. 2C, D). During transformation, size of apical meristem increases, the apex widens and flattens. Floral meristem consists of sequential cell layers and meristematic cells have mildly bigger volume and dense cytoplasm. The width of floral meristem is more than the width of apical meristem; however, the depth of floral meristem is lesser (Fig. 2A, C). In both apical and floral meristem cells, the intercellular spaces are considerably small. In following stages, floral meristem forms floral organ primordia.

The only difference in apical meristem stage is that the apical meristem of the pistillate florets is not as apparent and curvaceous as the apical meristem of the hermaphrodite floret (Fig. 2A, B). The differentiation of apical meristem into floral meristem is in the same progress in hermaphrodite and pistillate florets. Differences in both florets arise after this stage.

\section{Initiation of petal primordium}

In hermaphrodite and pistillate florets, the firstly differentiated structures from floral meristem are petal primordia (Fig. 2 C, D). Five petal lobes appear as a bulge from floral meristem's sides. Up to this stage, differentiation of petal primordia takes place in the same way in both florets.

In early stages of development, petal primordia lengthen equivalently and form a wide dome in hermaphrodite floret. In following stages, this five petal primordia come close to each other and form tubular corolla which surround androecium and gynoecium (Fig. $2 \mathrm{~K}$ ).

In early stages of development, five petal primordia lengthen unequivalently, merge laterally and form ray corolla in a mature pistillate floret. As a result of petals merge laterally, it appears as if there is a petal of ray shape (Fig. 2L).

\section{Initiation and development of stamen primordium}

Main difference of hermaphrodite and pistillate floret development comes into existence as from this stage.

In hermaphrodite florets, shortly after the differentiation of petal primordia, five stamen primordia differentiate as a roundish bulge from both sides of floral meristem
(Fig. 2C). In this stage, stamen primordia start to emerge, floral meristem flatness becomes increasingly convex. When stamen primordia start to lengthen, their roundish lines disappear slowly and their apex becomes more incisive (Fig. 2E).

During lengthening, firstly filament and then anther differentiates. In following stages, anther grows more rapidly than filament. In the following stages of development, anthers expand, grow rapidly and their apex start to get a pointed appearance (Fig. 2I). During the development of anthers those differentiate on filament, five anthers, come close to each other and grow as a pipe that surrounds style (Fig. 3C). Thus, five stamens whose anthers are fused and filaments are free surrounds the style like a pipe or tube (Fig. 2K).

In young hermaphrodite floret, tops of anthers are sharp and filaments are short (Fig. 3A, B). Anthers of mature florets are longer, wider and have more sharp tops than anthers of young florets (Fig. 3C, D). Filaments of mature florets are longer than filaments of young florets and seem curved (Fig. 3E). In both young and mature hermaphrodite florets, the tops of anthers have trichomes (Fig. 3B, D).

While five stamen primordia differentiate from floral meristem in a hermaphrodite floret, they don't differentiate in a pistillate floret, as a result, anther and filament don't arise. Pistillate florets pass directly from the periant initiation to the start of carpel formation and these florets do not carry a trace about the stamen primordium.

\section{Initiation and development of carpel primordium}

Female organ development starts with the differentiation of two carpel primordia out of floral meristem in hermaphrodite floret. Shortly after the stamen initiation, floral meristem cells differentiate into two carpel primordia. The carpel primordia become visible as two protuberances located below the stamen (Fig. 2E). Freshly emerged carpel primordia are not as roundish as stamen primordia, and their apexes are in a little bent-long structure. In these stages, where stamen primordia start to lengthen and carpel primordia start to emerge out of floral meristem, floral meristem flatness becomes non-visible. Two carpel primordia start developing and curve to the centre forming an ovarian cavity between them and this cavity shows to be the origin of gynoecium (Fig. 2G). In following stages, carpel primordial cells undergo mitotic divisions and carpel primordia lengthened upwards and formed a solid style above ovary (Fig. 2I). Carpel primordia continue their development, as they unit and produce a belt structure at upper part of ovarian cavity. Ovary arises by the time this belt structure is completed (Fig. $2 \mathrm{~K}$ ). Ovary starts inflating during development.

While style continues to prolonge, a stigma evolves out of its tip. It has two parts or branches which are covered with dense papillae. Two branches of stigma are closed and stigmatic papillae are not very dense in young florets (Fig. 


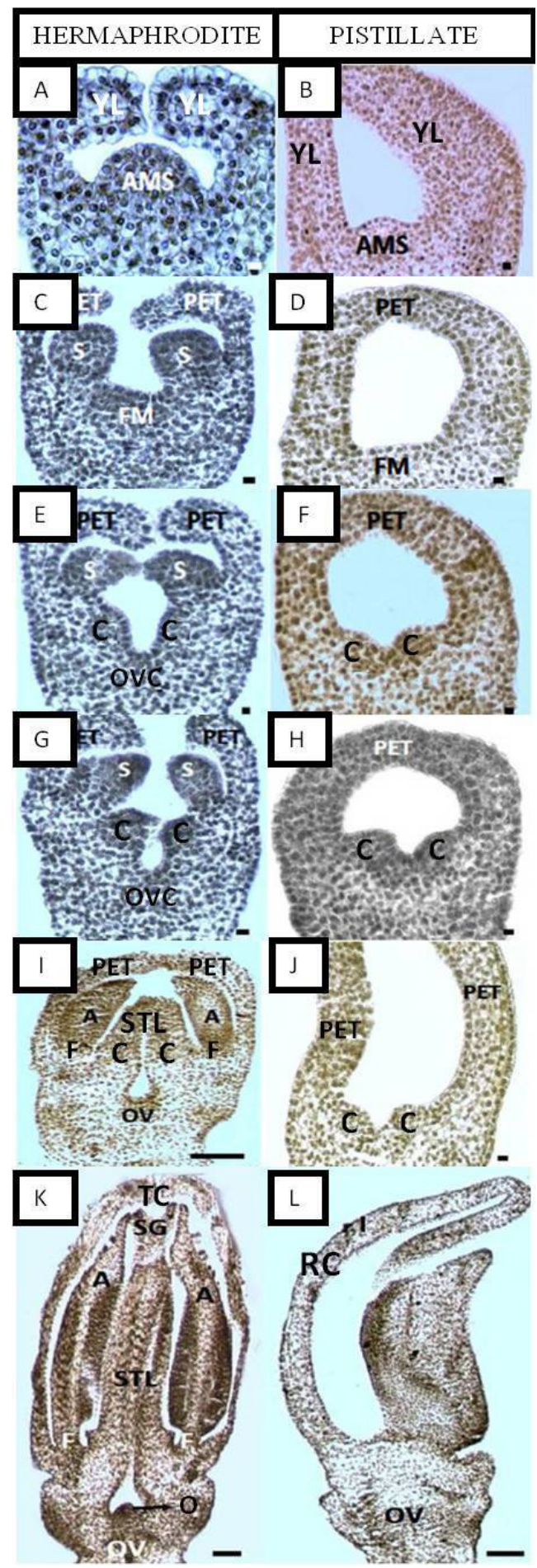

Fig. 2. Comparative floret development of hermaphrodite (left) and pistillate (right) florets in $H$. annuus (in longitudinal sections). A. Apical meristem initiation; B. Apical meristem initiation; C. Floral meristem and initiation of petal and stamen primordia from floral meristem; D. Floral meristem and initiation of petals from floral meristem; E. Lengthening petal primordia and two carpel primordial starting to differentiate out of floral meristem below lengthening stamen primordia; F. Lengthening petal primordia and two carpel primordia differentiate out of floral meristem; G. Stamens in which anther and filament differentiation start and the bent structure that the carpel primordia generated above ovary; H. Stage where carpel primordia development stops; I. Anthers starting to expande, short filaments, ovary and style that is generated when carpel primordia lengthen; J. Carpel primordia stopping development and petal primordial continuing to extent; K. Long and wide anthers, filaments, stigma with two parts, style, ovary with an ovule protruding out of placenta, tubular corolla in mature hermaphrodite flower; L. Carpel primordia disappeared and radial corolla in a mature pistillate flower. A: Anther; AMS: Apical meristem; C: Carpel; F: Filament; FM: Floral meristem; O: Ovule; OV: Ovary; OVC: Ovary cavity; PET: Petal; S: Stamen; SG: Stigma; STL: Stylus; YL: Youthful leaves. Bar: $10 \mu m$ (A-H), $100 \mu m(I-L)$ 
34
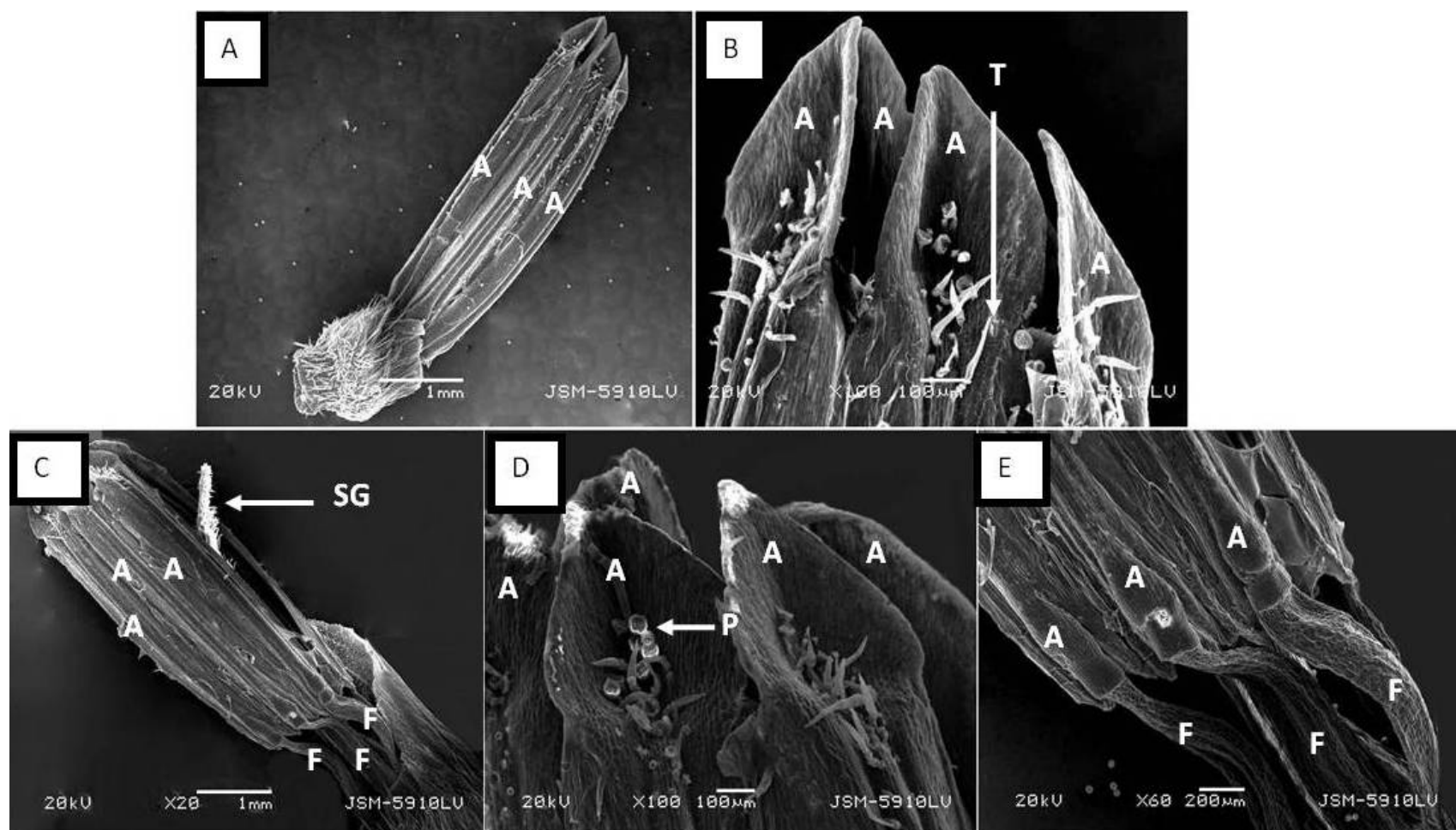

Fig. 3. SEM analysis of stamens in young $(\mathrm{A}, \mathrm{B})$ and mature hermaphrodite $(\mathrm{C}, \mathrm{D}, \mathrm{E})$ florets in $\mathrm{H}$. annuus. A. Long anthers and short filaments; B. Anthers with sharp tops and trichomes; C. Long anthers, long filaments, anther tube and stigma that is divided in two parts and stretched out from anther tube; D. Anthers with sharp tops and trichomes; E. Long and curled filaments. A: Anther; F: Filament; P: Pollen; SG: Stigma; T: Trichomes

4A). Two parts of stigma start widening while floret are maturing and they might reach out of the tube which anthers developed (Fig. 3C). In mature florets, stigmatic branches are covered very dense papillae. The papillae, which are on the upper part of stigmatic branches are rounded and short, although the papillae, which are on the lower part of stigmatic branches are sharp line and long (Fig. 4B)

In stage of style differentiation takes place, the ovule arises as a small homogeneous mass on the placenta in the ovary (Fig. 2K; Fig. 5A). In the following stages, ovule starts to curve (Fig. 5B).
Since, stamens does not exist in pistillate florets, florets pass directly from the periant development initiation to the start of carpel formation. Similarly to the process in hermaphrodite florets, two carpel pimordia differentiate out of floral meristem leaving an ovarian cavity (Fig. 2F). However, shortly after the differentiation, carpel development in pistillate florets ceases (Fig. $2 \mathrm{H}, \mathrm{J}$ ) and ovary fails to develop out of ovarian cavity, stigma and style development is not observed. However, an inferior ovary with no ovule forms (Fig. 2L).
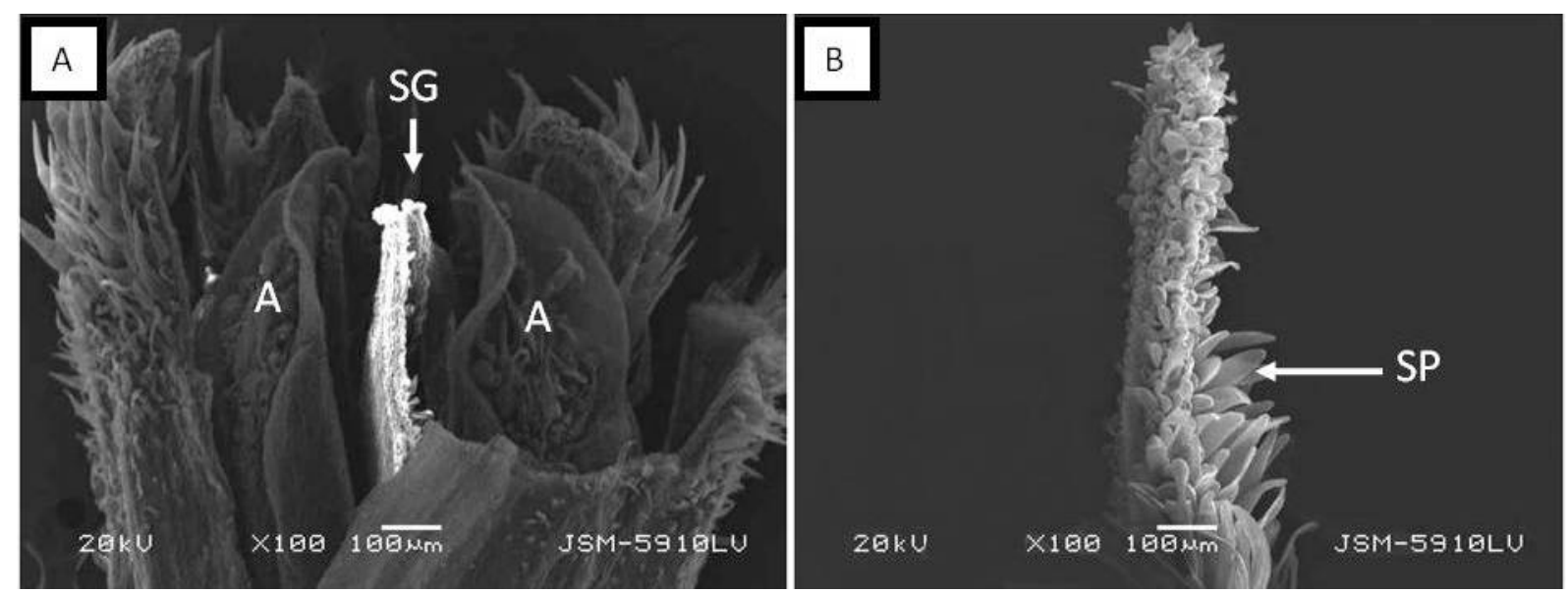

Fig. 4. SEM analysis of stigma in young (A) and mature (B) hermaphrodite florets in H. annuus. A. Stigma that is not divided in two parts in young floret; B. Stigmatic papillae in mature floret. A: Anther; SG: Stigma; SP: Stigmatic papillae 

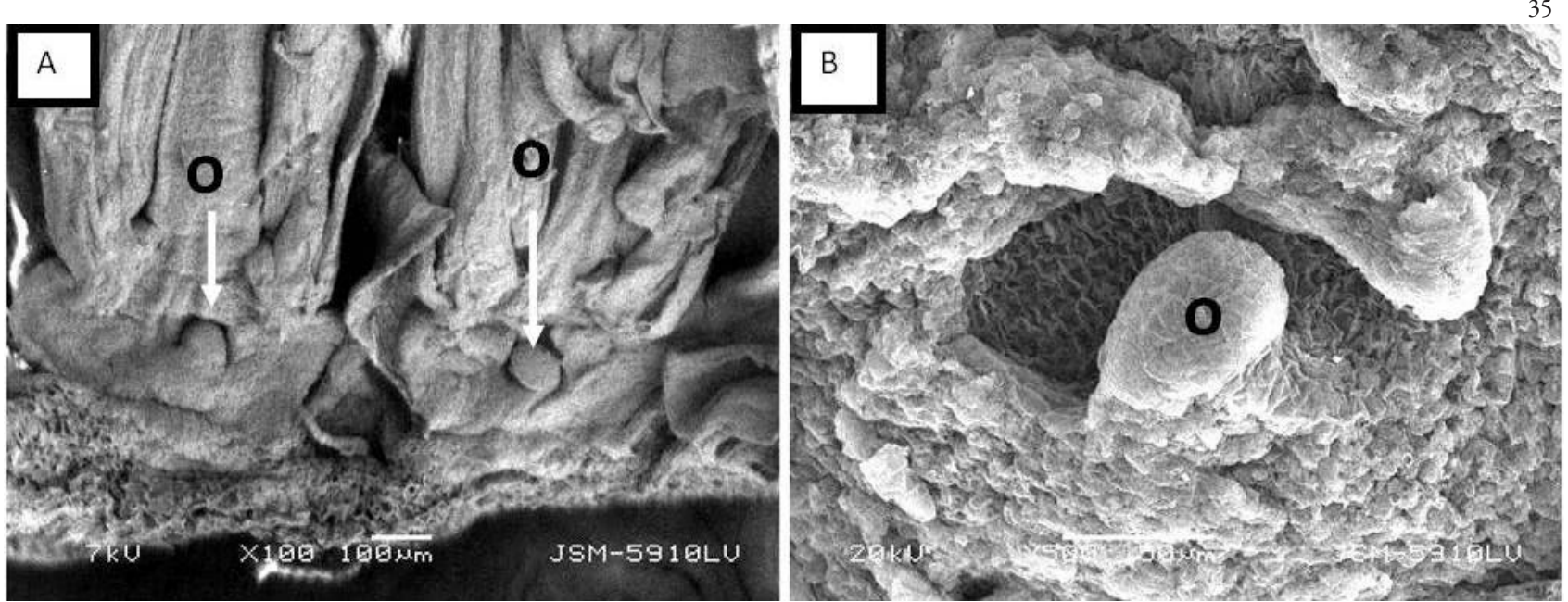

Fig. 5. SEM analysis of ovules in mature hermaphrodite florets in $H$. annuus. A. Arising ovules in two florets; B. Arising ovule starting to curve. O: Ovule

A little after carpel primordium arised in pistillate flowers, the primordial cells lengthened and stained darker. Due to the reason that growing lengthwise and being stained in dark are among characteristics of atrophied cells, it was commented that carpel primordial development stopped in this stage (Fig. $2 \mathrm{H}$ ).

It is one of several shared hermaphrodite and pistillate floret developments' characteristics that the number of carpel primordia is two and these primordia form an ovarian cavity (Fig. 2E, F). Since carpel primordia development ended after a time in pistillate florets, this ovarian cavity is not immensely apparent compared to the one in hermaphrodite florets.

\section{Development of florets in various whorls on capitulum}

Hermaphrodite floret development on a capitulum starts on the outermost whorl, and it progresses towards inner whorl. Hermaphrodite florets in outer whorls are al- ways more advanced than those in inner whorls in terms of development. Thus, hermaphrodite florets, which are in different stages of development on a capitulum that is close to maturity, might remain together. However, this does not occur in pistillate florets.

Fig. 6 shows that, florets, in different stages of development, are located together on the same capitulum. While flower development in outer whorls ended and seeds produced, blossoming in middle whorls just started, and blossoming has not started in inner whorls, and their ovary is quite small. In other word, floral initiation in sunflower occurs by centripetally.

On the same capitulum, florets of different whorls are at various developmental stages from outer whorl to inner whorl in capitulum (Fig. 7). Stamen primordia has already developed and started to lengthen in the outmost floret (floret number 1) of capitulum. Moreover, anther-filament differentiation started. Two carpel primordia started to

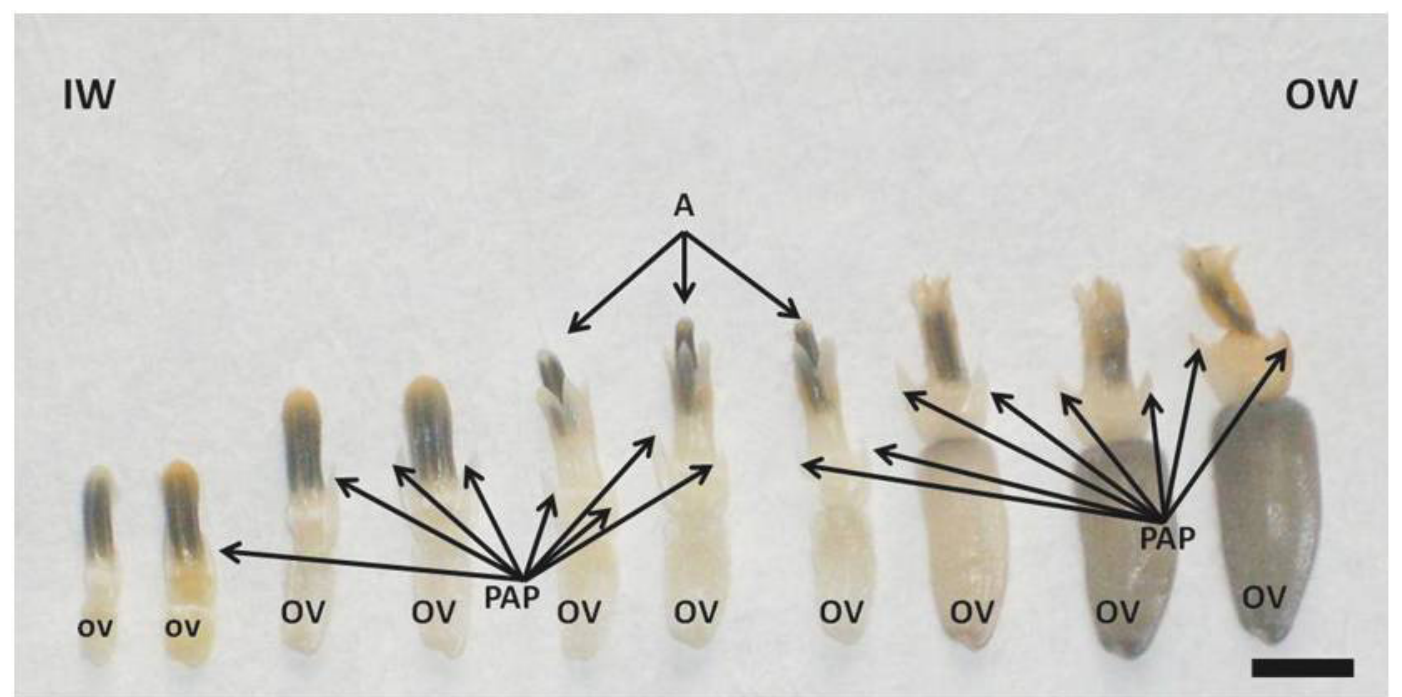

Fig. 6. Hermaphrodite florets which are in different stages of development on a mature capitulum in $H$. annuus. A: Anther; IW: Inner whorl florets; OV: Ovary; OW: Outer whorl florets; PAP: Pappus. Bar: $5 m m$ 


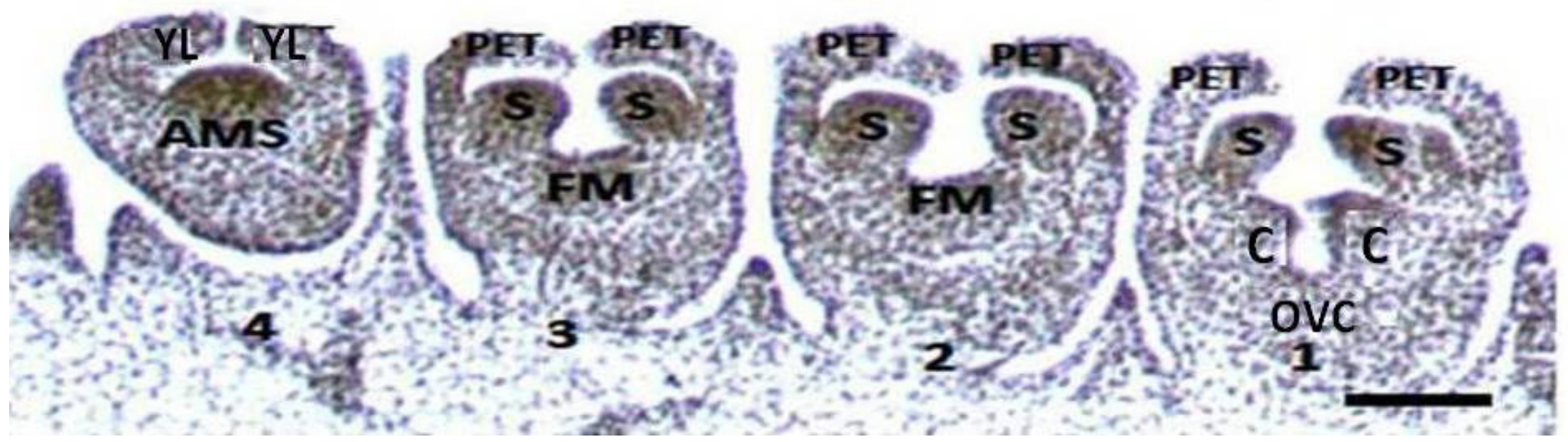

Fig. 7. Floret 1: stamen and carpel primordia become completely visible and ovarian cavity appeared, floret 2 and 3: stamen primordia become completely visible; floret 4: apical meristem become completely visible on the same capitulum in $H$. annuus (in longitudinal section). AMS: Apical meristem; C: Carpel; FM: Floral meristem; IW: Inner whorl flower; OVC: Ovarian cavity; OW: Outer whorl flower; PET: Petal; S: Stamen; YL: Young leaves. Bar: $100 \mu \mathrm{m}$

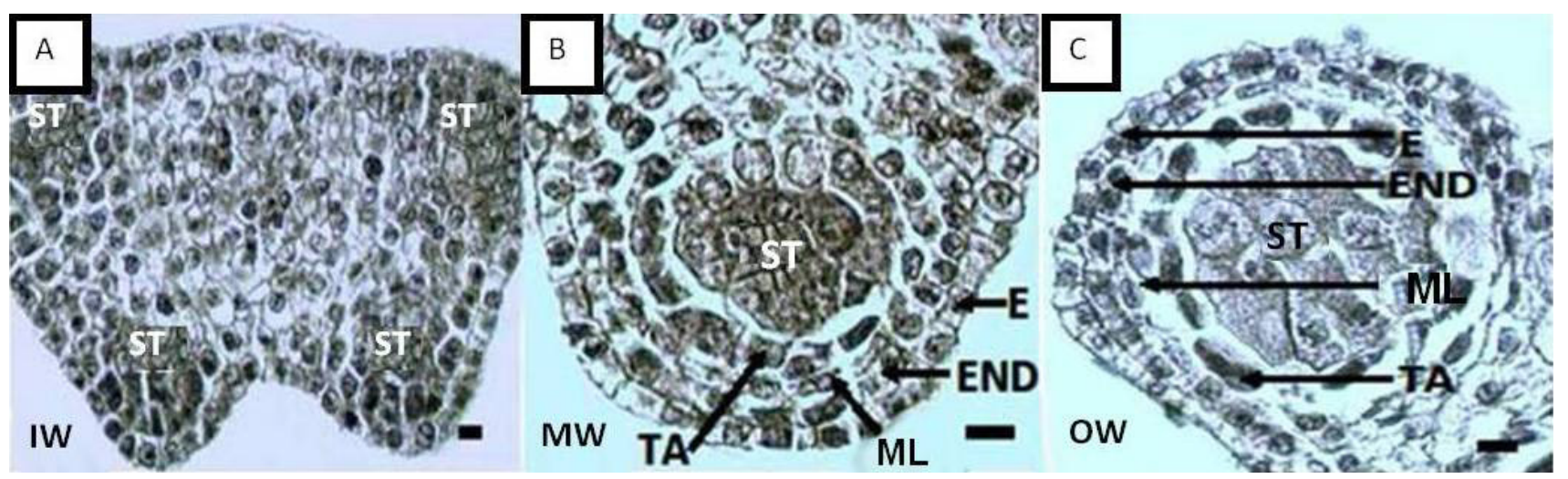

Fig. 8. Anthers of hermaphrodite florets in inner, medial and outer whorl of the same capitulum in $H$. annuus (in transverse section). A. The anther become slightlyl lobed and sporogenous tissue started to become visible in the floret of the inner whorl; B. Wellarranged anther wall layers and tapetal cells in the floret of medial whorl; C. Tapetal cells undergoing divisions in the floret of outer whorl. E: Epidermis; END: Endothecium; IW: Inner whorl floret; ML: Middle layer; MW: Medial whorl floret; OW: Outer whorl floret; ST: Sporogenous tissue; TA: Tapetum. Bar: $10 \mu \mathrm{m}$
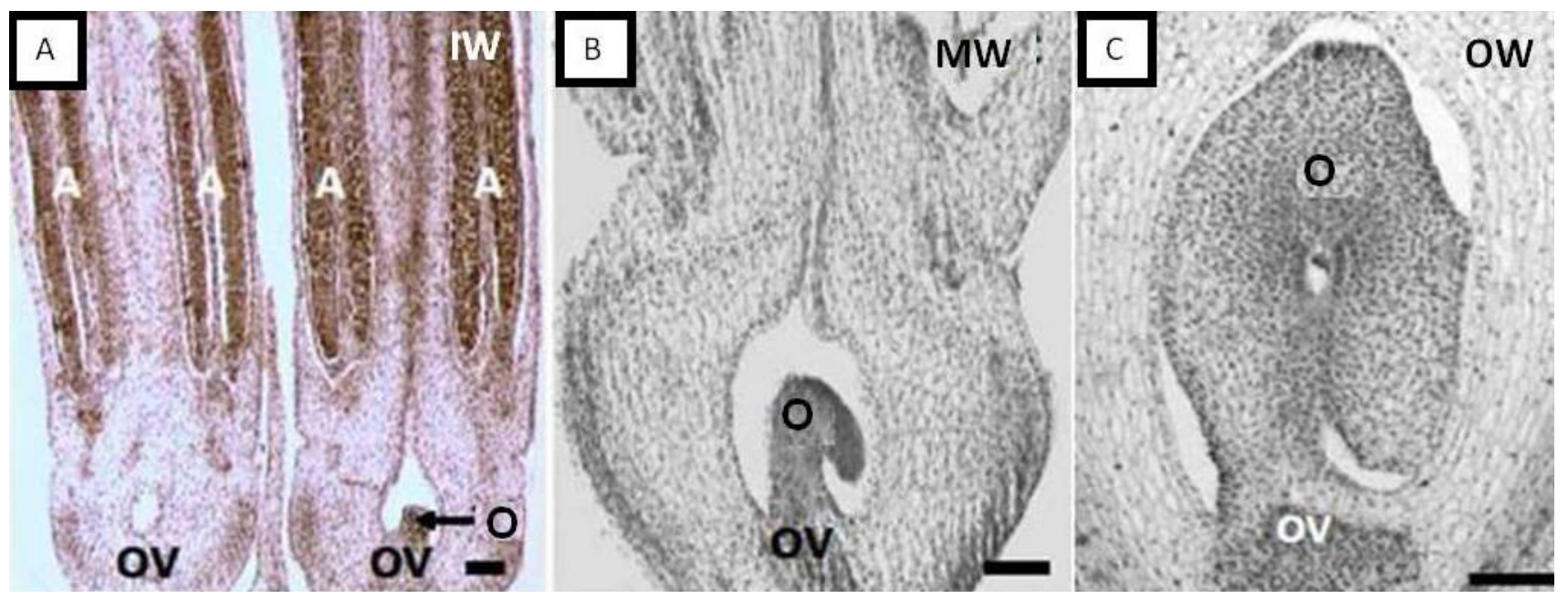

Fig. 9. Ovules at different development stages in hermaphrodite florets located on the same capitulum in $H$. annuus (in longitudinal sections). A. In inner whorl, floret without an ovule and floret with an ovule; B. In medial whorl, floret with an ovule starting to curve; C. In outer whorl, floret with fully developed anatropous ovule with an embryo sac. A: Anther; IW: Inner whorl floret; MW: Medial whorl floret; O: Ovule; OV: Ovarium; OW: Outer whorl floret. Bar: $100 \mu \mathrm{m}$ 


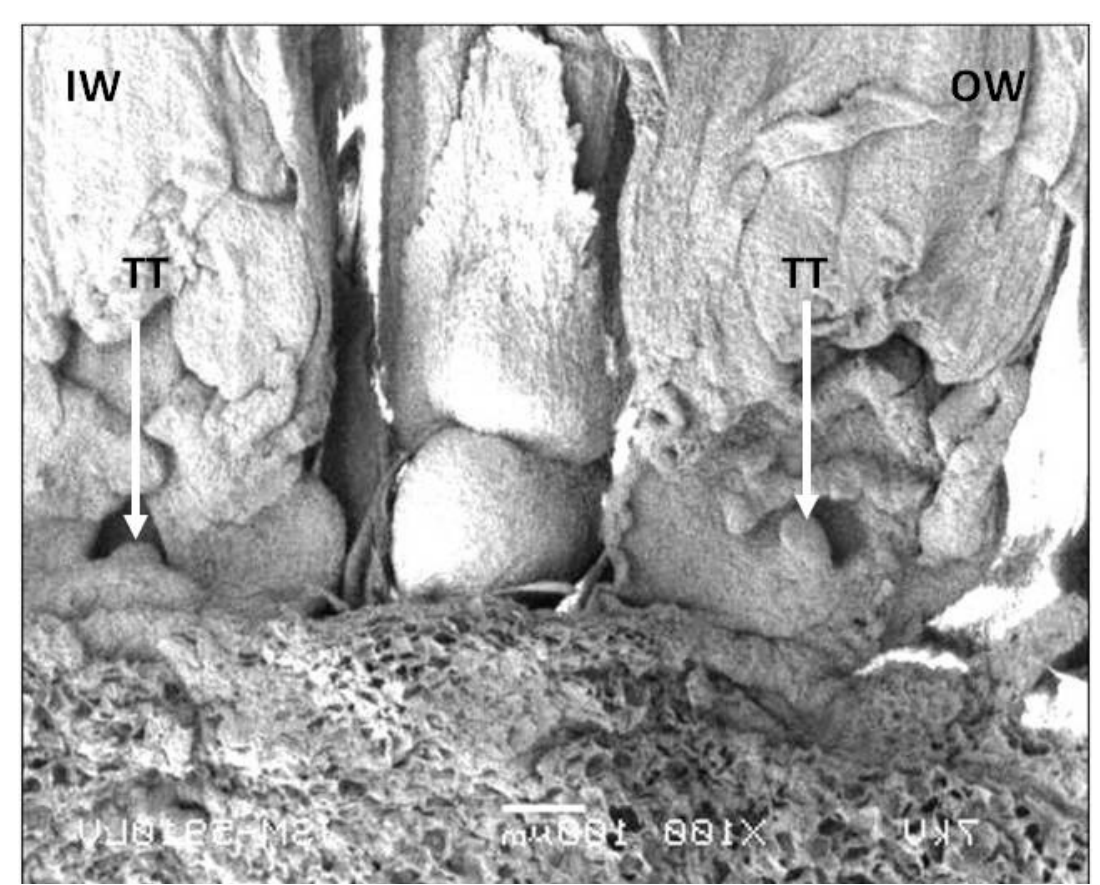

Fig. 10. SEM analysis of ovules in the florets located side by side in capitulum of $H$. annuus. OW: Outer whorl floret, IW: Inner whorl floret, O: Ovule

differentiate below stamen primordia generating an ovarian cavity between them. While outermost floret is in this stage, stamen primordia has just become visible in two florets (florets numbered 2 and 3 ) which located sequentially in two inner whorls of capitulum. Carpel primordia have not differentiated out of floral meristem yet. In floret in fourth whorl, apical meristem became visible as a bulge in a roundish form (floret number 4 ) and not transform into floral meristem yet.

Fig. 8 shows the development of an anther in the whorls of florets of the same capitulum. The anther of the innermost floret becomes slightly lobed. The number of sporogenous cells is a few (Fig. 8A). In medial whorl, the layers of anther wall become obvious and the number of sporogenous cells increase (Fig. 8B). In outermost whorl, while pollen mother cells originated from sporogenous cells start to early meiosis I, tapetal cells undergo mitotic divisions (Fig. 8C).

Ovule development takes place in a centripetal manner, as in male organ development (Fig. 10). While meiosis proceeds in pollen mother cells in male reproductive organ, ovules start to differentiate as a small bulge on the placenta in ovarian cavity in the floret of inner whorl (Fig. 9A). At this stage the ovule looks orthotropous. In the medial whorl, the ovule starts to curve (Fig. 9B) and it assumes its final anatropous shape in outer whorl (Fig. 9C).

After all data were obtained, diameters of capitulum buds were measured, development statuses of hermaphrodite florets in outer, medial and inner whorls and pistillate florets were assigned and are presented on Tab. 1 .

Tab. 1. Comparative developmental processes in the whorls of hermaphrodite and pistillate florets in respect of the diameter of capitulum bud in Helianthus annuus L.

\begin{tabular}{|c|c|c|c|c|}
\hline \multirow{2}{*}{$\begin{array}{l}\text { Capitulum bud } \\
\text { diameter }(\mathrm{mm})\end{array}$} & \multicolumn{3}{|c|}{ Hermaphrodite flower development process in outer, medial and inner whorls } & \multirow{2}{*}{$\begin{array}{c}\text { Pistillate flower } \\
\text { development process }\end{array}$} \\
\hline & Inner whorls & Medial whorls & Outer whorls & \\
\hline$<1 \mathrm{~mm}$ & Pre-reproduction stage & $\begin{array}{l}\text { Apical meristem } \\
\text { become visible }\end{array}$ & Floral meristem become visible & Pre-reproduction stage \\
\hline$\sim 1 \mathrm{~mm}-3 \mathrm{~mm}$ & $\begin{array}{l}\text { Apical meristem } \\
\text { become visible }\end{array}$ & $\begin{array}{l}\text { Apical meristem become } \\
\text { visible and stamen arise }\end{array}$ & Stamen primordia arise & Apical meristem arise \\
\hline$\sim 3 \mathrm{~mm}-5 \mathrm{~mm}$ & $\begin{array}{c}\text { Floral meristem become } \\
\text { visible and stamen } \\
\text { primordia arise }\end{array}$ & Stamen primordia are visible & $\begin{array}{l}\text { Carpel primordia arise } \\
\text { and anther-filament } \\
\text { differentiation occur }\end{array}$ & Carpel primordia arise \\
\hline$\sim 5 \mathrm{~mm}-9 \mathrm{~mm}$ & $\begin{array}{c}\text { Stamen primordia } \\
\text { are visible }\end{array}$ & $\begin{array}{l}\text { Carpel primordia arise } \\
\text { and anther-filament } \\
\text { differentiation occur }\end{array}$ & $\begin{array}{l}\text { Ovary, style and stigma } \\
\text { form and anther-filament } \\
\text { differentiation completed }\end{array}$ & $\begin{array}{l}\text { Further deveopment of } \\
\text { carpel primordia stops }\end{array}$ \\
\hline$\sim 9 \mathrm{~mm}-13 \mathrm{~mm}$ & $\begin{array}{l}\text { Carpel primordia arise } \\
\text { and anther-filament } \\
\text { differentiation occur }\end{array}$ & $\begin{array}{l}\text { Ovary, style and stigma } \\
\text { form and anther-filament } \\
\text { differentiation completed }\end{array}$ & $\begin{array}{l}\text { Ovule become visible in } \\
\text { inferior ovary and } \\
\text { anthers mature }\end{array}$ & $\begin{array}{c}\text { No stigma and style } \\
\text { differentiation, only inferior } \\
\text { ovary with no ovule }\end{array}$ \\
\hline
\end{tabular}


38

\section{Discussion}

In Asteraceae family, the single inflorescence may contain six types of florets (Herman, 2000). For instance, in Neptunia pubescen, three types of florets exist; hermaphrodite, staminate and neutral (Tucker, 1988). However, in $H$. annuus, there are two types of florets on a capitulum; tubular, hermaphrodite floret and pistillate, ray floret. Heiser (1978) and Seiler (1997) described ray florets as neutral or pistillate florets. However in the present study, ray florets were described as pistillate florets due to the fact that carpel primordium differentiation was observed during development. The hermaphrodite florets of both $X$. squarrosum and $H$. annuus demonstrate resemblance, morphologically. In hermaphrodite florets of $X$. squarrosum, there is a tubular corolla that was formed when five petals converged, and there is also an anther tube that emerged when filaments freed, and anthers fused (Dadpour et al., 2011).

Apical meristem differentiates as a roundish bulge in early stages of flower development in $H$. annuus, and it consists of sequential cell layers as it is also in Silene latifolia (Grant et al., 1994). The morphological changes, observed during the conversion of apical meristem to floral meristem, resemble the ones in tomato; apical meristem grows in size, apical apex widens and flattens (Chandra and Sawhney, 1984; Granados, 1996; Grant, 1994). According to the study of Teeri et al. (2006), the flattening and expansion of floral meristem occurs as a result of the increase in division rates of the cells in the centre of floral meristem.

In hermaphrodite floret of $H$. annuus L., the first structure that differentiates out of floral meristem is five petal primordia, as it is also the case in the hermaphrodite floret of $X$. squarrosum, and in the following stages, petals unite as a tube to develop tubular corolla (Dadpour et al., 2011). Five petal lobes differentiate out of floral meristem in the pistillate floret of $H$. annuus's, and in the following stages, they lengthen unequally, unite laterally to develop radial corolla. In radial pistillate flower of Greenhouse chrysanthemums, which is the hybrid of Chrysanthemum hortorum Hort. and Dendranthema grandiflora Hort., as well, five petal lobes differentiate out of floral meristem. However, the development of two petal lobes stops, and three developing petal lobes lengthen equally, align laterally to develop radial corolla (Kuklina, 2003).

As in other plants (Uhl, 2011), all floral organ primordia in $H$. annuus develop as a result of periclinal division of floral meristem cells. In hermaphrodite flower of $H$. annu$u s$, stamen primordia arise in roundish bulge forms as they do in Lactuva sativa (Jones, 1927), and stamens emerge synchronized as they do in Erigeron philadelphicus (Harris et al., 1991). Stamen primordia arise out of the sides of floral meristem, as Dadpour et al. (2011) stated, and in stages where stamen primordia start emerging, the flatness of floral meristem starts to become gradually convex. Five stamens, whose anthers are fused and filaments are free in $H$. annuus, surround the style like a pipe or tube, and this structure is called anther tube (Ericson et al., 1985). Many trichomes are present in the acral parts of anthers in hermaphrodite florets of $H$. annuus. The functions of these trichomes are not clarified, yet (Ericson, 1983). However, they are thought to contain chemical agents those are can repress bugs or, in direct contradiction, allure them (Kreitner, 1980).

The arrest time of stamen and pistillate development varies among species. The spectrum interval of unisexual flower development revolutionizes from the differentiation of organ primordia until the formation of sex organs, which are completely developed but non-functional (Dellaporta ve Calderon-Urea, 1993). Stamen primordia do not differentiate out of floral meristem in pistillate floret of Helianthus annuus, and these florets do not carry a trace about the stamen primordium. Pistillate florets pass directly from the periant development initiation to start of carpel formation, and they do not contain the opposite sex organ primordium. Similar to pistillate floret of $H$. annuus, flowers of some species do not perform any proof of sex loss. Pistillate flower developes with the carpel differentiation after periant inception in Cannabis sativa, as well, and stamen primordia in this flower are undistinguishable (Ram and Nath, 1964). Unisexual flowers do not contain organ primordium of opposite sex from the floral meristem stage in Mercuralis species, as well (Durand and Durand, 1991). However, sex determination in pistillate flower of Zea mays arises as a result of programmed cell death of stamen primordia (Bonnet, 1948; Cheng, 1983). In pistillate floret of $X$. squarrosum, which is an Asteraceae species, four stamen primordia differentiate out of floral meristem, however, stamen primordia atrophy in following stages (Dadpour et al., 2011). Both stamen and carpel primordia initiation take place in pistillate flowers of Silena dioica, and sex determination occurs when mature stamen development ends (Atsmon and Galun, 1960; Malepszy and Niemirowicz, 1991). Pistillate flower in Asparagus officinalis, can not be distinguished phenotypically until meiosis starts in ovules and stamens. With the conclusion of pollen formation, the sex of flower is determined (Bracale, 1991; Lazarte and Palser, 1979).

Female organ development starts with arise of carpel primordium in the center of floral meristem in sunflower, as it is a usual manner in flowering plants (Gasser and Beers, 1993). Two carpel primordia start development, leaving a small ovarian cavity between them, in $H$. annuus, and it determines the origin of the gynoecium. The carpel primordia, which just arise in hermaphrodite floret of $H$. annuus, are not as roundish as stamen primordia, and their apex is in bent-long structure. Uhl (2011) mentioned that various floral organs those differentiate out of floral meristem, might be morphologically different. Lengthening above the ovary cavity, carpel primordia form style in 
hermaphrodite florets. A similar development model was defined in Lactuca sativa, as well (Jones, 1927).

As it is in pistillate floret of $X$. squarrosum (Dadpour et al., 2011), two carpel primordia arise out of floral meristem, however, their development stops after a time. Stigma and style do not develop. An inferior ovary, which does not contain ovule, arises. Radial florets which do not produce seed in Compositae family, are considered, functionally, as the analog of petals (Mani and Saravanan, 1999), and they secure that inflorescence are frequently visited by bugs (Nielsen et al., 2000).

Arise and development of hermaphrodite florets on the capitulum in $H$. annuus L. starts in the outer whorls of capitulum, and continues towards inner whorls in oneway form. However, in Erigeron philadelphicus L. which is a Compositae species, arise and development of hermaphrodite florets on capitulum start in the midmost whorls of the capitulum, and it continues a duplex trip towards inner and outer whorls (Harris et al., 1991).

\section{Conclusions}

The present study reveals that the comprehensive descriptions of hermaphrodite and pistillate florets in $H$. annuus differ from each other. The development in a hermaphrodite floret occurs in the following sequence: conversion of apical meristem to floral meristem; initiation of petals; initiation of stamens and carpels. In pistillat flower it follows this order: conversion of apical meristem to floral meristem; initiation of petals; initiation of carpels, the development of which stops in a short time.

\section{Acknowledgments}

This work was supported by the Research Foundation of Marmara University (BAPKO no: FEN-CYLP-031210-0294).

\section{References}

Anderberg AA, Baldwin BG, Bayer RG, Breitwieser J, Jeffrey C, Dillon MO, Eldenas P, Funk V, Garcia-Jacas N, Hind DJN, Karis PO, Lack HW, Nesom G, Nordenstam B, Oberprieler C, Panero JL, Puttock C, Robinson H, Stuessy TF, Susanna A, Urtubey E, Vogt R, Ward J, Watson LE (2007). Compasitae, the families and genera of vascular plants. Springer, Berlin 8:61-588.

Atsmon D, Galun E (1960). A morphogenetic study of staminate, pistillate and hermaphrodite flowers in Cucumis sativus L. Phytomorphol 10:110-115.

Aytürk Ö, Ünal M (2012). The analysis of sex identification in dioecious Laurus nobilis L. Not Sci Biol 4(1):31-43.

Bernier G, Havelange A, Houssa C, Petitjean A, Lejeune P (1993). Physiological signals that induce flowering. Plant Cell 5:1147-1155.

Bonnet OT (1948). Ear and tassel development in maize. Ann
Mo Bot Gard 35:269-287.

Bracale M, Caporali E, Galli MG, Longo C, Marziani LG, Tassi F (1991). Sex expression and determination in Asparagus officinalis. Plant Sci 80:67-77.

Chandra SKN, Sawhney VK (1984). A scanning electron microscope study of the development and surface features of floral organs of tomato (Lycopersicon esculentum). Can J Bot 62:2403-2413.

Cheng P, Greyson C, Walden D (1983). Organ initiation and the development of unisexual flowers in the tassel and ear of Zea mays. Am J Bot 70:450-462.

Dadpour MR, Naghiloo S, Neycaran SF (2011). The development of pistillate and perfect florets in Xeranthemum squarrosum (Asteraceae). Plant Biol 14:234-243.

Dellaporta SL, Calderone-Urrea A (1993). Sex determination in flowering plants. Plant Cell 5:1241-1251.

Durand B, Durand R (1991). Sex determination and reproductive organ differentiation in Mercurialis. Plant Sci 80:49-65.

Erickson EH, Sammataro D, Garment MB (1985). Anatomical features of the sunflower floret. Helia (FAO, Romania):25-31.

Ericson EH (1983). Hybrid sunflowers, $522-535$ p. In: Jones CE, Little RJ (Eds.). Handbook of experimental pollination biology. Van Nostrand Reinhold, New York.

Frankel R, Galun E (1977). Pollination mechanisms, reproduction, and plant breeding. Springer, Berlin.

Gasser S, Beers K (1993). Pistil development. Plant Cell 5:12311239.

Gotelli M, Galati B, Medan D (2008). Embryology of Helianthus annuus L. (Asteraceae). Ann Bot Fennici 45:81-96.

Granados E (1996). World olive encyclopaedia. International olive oil council. Principe de Vergara 154, 28002 Madrid, 44 p. (Spain).

Grant S, Houben A, Vyskot B, Siroky J, Pan WH, Macas J, Saedler $H$ (1994). Genetics of sex determination in flowering plants. Dev Genet 15:214-230.

Harris EM (1999). Capitula in the Asteridae: a widespread and varied phenomenon. Bot Rev 65:348-369.

Harris EM, Tucker SC, Urbatsch LE (1991). Floral initiation and early development in Erigeron philadelphicus L. (Asteraceae: Astereae). Am J Bot 78:108-121.

Haughn GW, Somerville CR (1988). Genetic control of morphogenesis in Arabidopsis. Dev Genet 9:73-89.

Heiser CB (1976). The Sunflower. University of Oklahoma Press, Norman, $198 \mathrm{p}$.

Heiser CB (1978). Taxonomy of Helianthus and origin of domesticated sunflower. Sun Sci Technol 19:31-53.

Herman PPJ, Retief E, Koekemoer M, Welman WG (2000). Asteraceae (Compositae) In: Leistner OA (Ed.). Seed plants of Southern Africa. National Botanical Institute, Pretoria, Strelitzia 10:101-170.

Hurd PD, Berge WE, Linsley EG (1980). Principle sunflower 
40 bees of North America with emphasis on the Southwestern United States (Hymenoptera: Apoidea). Zool 310:158.

Jones $H$ (1927). Pollination and life history studies of lettuce (Lactuca sativa L.). Hilgardia 2:425-497.

Kinet J, Sachs RM, Bernier G (1985). The physiology of flowering, Vol. III: Development of flowers. CRC Press. Boca Raton, New York, $274 \mathrm{p}$.

Knowles PE (1978). Morphology and anatomy, in: Sunflower science and technology. Am Soc Agron Crop, Madison WI 55-85 p.

Kreitner GL, Gershenzen J (1980). Secretory structures of disk florets as possible source of chemical resistance to sunflower Moth larvae. ESA, 639 p.

Kuklina EA (2003). Flower development of Greenhouse chrysanthemum. ABCS Botanica 45(1):173-176.

Lazarte JE, Palser BF (1979). Morphology, vascular anatomy, and embryology of pistillate and staminate flowers of Asparagus officinalis. Am J Bot 66:753-764.

Malepszy S, Niemirowicz Szczytt NK (1991). Sex determination in cucumber (Cucumis sativus) as a model system for molecular biology. Plant Sci 80:39-47.

Mani MS, Saravanan JM (1999). Pollination ecology and evolution in Compositae (Asteraceae). Science Publishers, Enfield, New Hampshire, USA.

McGregor SE (1976). Insect pollination of cultivated crop plants, Agriculture handbook No: 496, United States Department of Agriculture, $411 \mathrm{p}$.

Nielsen LR, Philipp M, Adsersen H, Siegismund HR (2000). Breeding system of Scalesia divisa Andersson, an endemic Asteraceae from the Galápagos Islands. Det Norske Videnskaps Akademi. I. Mat. Naturv. Klasse, Skrifter, Ny Serie 39:127-138.
Platt AKA, Oross JW, Thomson WW (1983). Ultrastructural study of the development of oil cells in the mesocarp of avocado fruit. Bot Gaz 144(1):49-55.

Ram HY, Nath R (1964). The morphology and embryology of Cannabis sativa L. Phytomorphol 14:414-429.

Rastogi R, Sawhney VK (1988). Suppression of stamen development by CCC and ABA in tomato floral buds cultured in vitro. J Plant Physiol 133:620-624.

Seiler GJ (1997). Anatomy and morphology of sunflower. Sunflower Technol Prod, Agron 35:67-111.

Teeri TH, Uimari A, Kotilainen M, Laitinen R, Help H, Elomaa P, Albert VA (2006). Reproductive meristem fates in Gerbera. Oxford J 57:3445-3455.

Topçuoğlu N, Selvi N, Dokumaci E (2009). The comparison of critical point drying and drying with Hexamethyldisilazane methods for the preparation of mice tissues for scanning electron microscopy II. Lung and stomach Findings. Anad Univ J Sci Techn 1:127-132.

Tucker CS (1988). Heteromorphic flower development in Neptunia pubescens, a mimosoid legume. Am J Bot 5(2):205224.

Uhl WN (2011). Developmental studies in Ptychosperma (Palmae). II. The staminate and pistillate flowers. Am J Bot 63(1):97-109.

Ye ZH, Varner JE (1991). Tissue-specific expression of cell wall proteins in developing soybean tissues. Plant Cell 3:23-37. 